\title{
Does Venture Capital Investment Lead to a Change in Start-Ups' Intellectual Property Strategies?
}

\author{
Philipp Sandner ${ }^{1}$, Christa Dufter ${ }^{2}$, Richard Geibel ${ }^{3}$ \\ ${ }^{1}$ Assistant Professor of Manufacturing, Frankfurt School of Finance \& Management, Frankfurt am Main, Germany \\ ${ }^{2}$ Research Association for Energy Markets and Technologies, Munich, Germany \\ ${ }^{3}$ Professor of Digital Management, University Fresenius of Applied Sciences, Cologne, Germany \\ Email:email@philipp-sandner.de,cdufter@ffe.de,geibel@hs-fresenius.de
}

How to cite this paper: Sandner, P., Dufter, C. and Geibel, R. (2016) Does Venture Capital Investment Lead to a Change in Start-Ups' Intellectual Property Strategies? American Journal of Industrial and Business Management, 6, 1146-1173.

http://dx.doi.org/10.4236/ajibm.2016.612107

Received: September 29, 2016

Accepted: December 23, 2016

Published: December 26, 2016

Copyright $\odot 2016$ by authors and Scientific Research Publishing Inc.

This work is licensed under the Creative Commons Attribution International

License (CC BY 4.0).

http://creativecommons.org/licenses/by/4.0/

\begin{abstract}
This paper examines the influence of venture capital (VC) funding on start-ups' intellectual property (IP) strategies. More specifically, the number of additionally filed patent and trademark applications after subsequent $\mathrm{VC}$ funding rounds is investigated. The results from the analysis of 531 start-ups show that VC funding has a strong influence on consecutive IP strategy. Already first funding rounds lead to a remarkable growth of start-ups' IP portfolios. Yet, although VCs especially promote product commercialization of start-ups, a greater growth of trademark compared to patent portfolios cannot be identified. However, this changes during the progress along the venture cycle.
\end{abstract}

\section{Keywords}

Entrepreneurial Finance, Venture Capital, Patents, Trademarks, Intellectual Property

\section{Introduction}

Start-ups face various challenges, especially during the early stages of their operations. These challenges are, however, not attributable to the potential lack of technological knowledge which is required to come up with innovations of products and services. Rather, the underlying problem is often caused by a lack of experience and expertise and, above all, by insufficient financial resources which young firms typically exhibit [1]. Nevertheless, these attributes are essential in order to transform new technologies into marketable products and services creating revenues and, ultimately, profits.

Previous research has shown that start-ups, among others, lack experience of the markets that their inventions target [2] as well as of marketing in general [3]. The ma- 
jor challenge, on the contrary, is the need to raise sufficient amounts of capital. Earlier research has identified start-ups as often being financially constrained [1] [4] and thus, they must enlist financial support from external sources [4] [5] [6]. With their assets mostly being intangible, several years of negative cash flows ahead and, above all, great uncertainty about their future prospects [1] [5] [7], bank loans and other kinds of traditional financing methods might not be appropriate alternatives [5] [8] [9]. In contrast, venture capitalists (VCs) seem to be much more eligible [7] [5] [10].

VCs, however, are not mere "silent partners" [10], but rather exert strong influence on the start-ups they finance. Among others, several studies suggest that VCs shape start-ups' intellectual property (IP) management, meaning the intensity of filing intellectual property rights (IPRs) in the form of patents and trademarks [10] [11] [12] [13]. Nonetheless, IP portfolios already play an important role at the beginning of the relationship between VCs and start-ups. When deciding whether to invest or not, it is difficult for VCs to evaluate a start-up and its ability to turn out profitable in the end (see e.g. [6] [14]). One prominent attempt to overcome these information asymmetries is to evaluate start-ups' IP assets such as patents and trademarks. In this context, patents and trademarks serve as quality signals for $\mathrm{VC}$ financing and therefore, contribute to a start-up's ability to attract VCs. Previous studies on the signaling value of patents have shown that having patents increases the likelihood of receiving VC funding for startups [14] [15] [16] [17] [18] as well as reduces the time to first VC financing [14] [19]. Furthermore, a positive influence of patents on VC financing amounts has been discovered [7] [9] [20]. Compared to research on the signaling value of patents, research on the signaling value of trademarks for start-ups is rather scarce [21].

Besides the impact of start-ups' patent and trademark portfolios on investment decisions-namely the signaling effect, the converse case has also been examined. Venturebacked firms are more likely to file patents [10] [13] and also have a higher number of patents [10] [12] [13]. Furthermore, an impact of VC funding on start-ups' trademark portfolios has been identified. Nevertheless, to the best of our knowledge, only De Vries et al. [11] have investigated this effect so far and revealed a positive relation.

Further linking the compositions of start-ups' IP portfolios before and after VC investments would provide an important contribution to existing research on the interrelation of VC funding and IP strategy of start-ups. There already is a small body of research on the influence of VCs on patent portfolios of start-ups. However, these studies have set a slightly different focus [12] [13] or investigated only a rather small number of venture-backed firms [10]. With regard to trademarking activity, the study of [11] has been the only one investigating this issue.

Hence, this study is to the best of our knowledge the first to close the gap and jointly compares patent and trademark portfolios before and after funding rounds across a large sample of U.S. start-ups. More specifically, it is examined whether VC investments shape start-ups' IP portfolios in terms of scope and composition. Furthermore, it analyzes whether and to what extent the stage of the venture cycle at which VC investments are received affects this influence. 
In this study, a large set of patent and trademark data of U.S. start-ups that have received VC funding between 1991 and 2009 is used to demonstrate that first VC funding rounds lead to a rise in the number of both patent and trademark applications. However, the assumption that the rise is more significant for trademarks compared to patents cannot be proved. Finally, the results imply a partially increasing effect of trademark applications with every subsequent funding round.

These findings provide several contributions to research on the interrelation between VC financing and IP strategy of start-ups. First, it adds to the body of research on start-ups' IP portfolios. Specifically, it contributes to a deeper understanding of the relationship between VC funding and IP portfolios [10] [11] [12] [13] by explaining why and to what extent start-ups' IP strategies are influenced by VC investments. Hence, this paper seeks to explain why the composition of start-ups' IP portfolios-with regard to the number of and proportion between patents and trademarks-changes after $\mathrm{VC}$ investment. Second, this study underpins that VCs promote commercialization [11] [19] [22]. Third, this study contributes to the literature on the varying importance of patent and trademarks at different stages during a start-up's development [9] [11].

This paper is structured as follows. Section 2 gives an overview of related literature. In section 3, hypotheses on the influence of VC investments on start-ups' IP portfolios are developed. Section 4 describes the data, variable definitions and method. In section 5, the descriptive and multivariate results are provided and discussed. Section 6 indicates the contributions of this study as well as its limitations and proposes directions for future research.

\section{Related Literature}

\subsection{Importance of Patents for Start-Ups to Protect Technology}

A patent grants its holder the right to exclude others from producing or using the underlying invention (e.g. [23] [24]) and thus, protects a firm's technological assets [11]. The protection is guaranteed for a limited period of time, usually twenty years [24]. During the time of protection, patents provide a competitive advantage for firms through the possibility of offering distinctive products or services, exploiting cost advantages or generating revenues from licensing activities [18] [25] [26]. However, the protection of technology through patents is associated with certain tangible and intangible costs (see e.g. [27] [28]). Whereas the tangible component consists of costs for the filing and defense of patents, the intangible part is related to the costs of information disclosure (see e.g. [27] [28]). Consequently, a firm will only decide to file a patent if the possible benefits resulting from the protection mechanism exceed the costs for filing the patent [27] [29].

In prior research, differences in the patenting behavior-meaning the intensity of as well as the reasons for patenting-across industries have been shown. Several studies have suggested that patents may be more important for industries such as pharmaceuticals and chemicals [30], whereas they are considered of less value in, for instance, software and internet industries [16]. Reference [25] has differentiated between discrete-such 
as chemicals-and complex industries-such as semiconductors-and investigated the underlying reasons for patenting. In the former, patents are used for defensive purposes whereas in the latter mainly for offensive reasons. Furthermore, the patenting behavior differs among service and manufacturing firms whereby patents are considered more important for the latter [31]. Nevertheless, not only industry characteristics influence patenting decisions, firm size has proven to be of similar importance. Several studies have identified patent intensity as being positively related to firm size (e.g., [10] [31] [30] [32]). The focus of this study, however, is on small firms-more specifically on small and new firms-namely start-ups.

Some of the benefits resulting from patenting show similarities between start-ups and larger firms. These involve mainly competitive advantages, preventing others from copying technology, and enhancing reputation (see e.g. [16] [25]), whereby the latter may be particularly important for start-ups [16]. Reference [15] considers a patent as "important asset that provides protection from imitation or a basis for contracting in the market for technology" for start-ups. Reference [25] has a similar view. They regard patents as facilitating negotiations with other firms by strengthening start-ups' positions.

Although patents provide several benefits for start-ups, the costs associated with the filing of patents are more likely to affect them, since they are typically constrained in terms of capital and staff. First, the direct costs related to the patenting process estimated at about USD 20,000 [29] may be regarded as a considerably high amount for start-ups [18]. Furthermore, they often lack resources needed for defending their patents [25] [33] —including monitoring possible violations and litigating in the case of infringement. Another important issue is the absence of funded knowledge regarding legal issues which is particularly crucial for defending a firm's IP [18].

Once start-ups have made the decision to patent, however, they typically exhibit better characteristics than their non-patenting peers. Several studies have revealed a positive correlation between patenting and subsequent performance. First, patenting activity has been found to increase firm survival [9] [33] [34] [35]. Second, it has been identified as being positively related to the probability of issuing initial public offerings (IPOs) [6] [7]. Third, [33] had found patenting to enhance growth rates. Another important aspect is the positive effect of patenting on subsequent firm valuation [18] [36].

\subsection{Importance of Trademarks for Start-Ups to Protect Market Access}

While patents are strongly related to a company's technology base and therefore to its research and development ( $R \& D$ ) activities, trademarks are connected to marketing activities [37]. A trademark is defined as a "distinctive sign which identifies certain goods or services as those produced or provided by a specific person or enterprise" [24]. It can be a word, name, phrase, symbol, or logo [38] [39]. In contrary to patents, the protection provided by trademarks can be perpetuated permanently [24] [28]. This creates the possibility to realize profits from an innovation after the initial protection by patents has expired [40]. The main benefit from filing trademarks is that it enables 
firms to differentiate their products from those of their competitors [35] [41] [42] and so, allows them to indicate "a certain level of quality or other characteristic" [35]. Thus, trademarks help to reduce consumer search costs [37] [42]. However, while a patent results in competitive advantages immediately after the grant decision, the benefits resulting from trademark filing require providing consistent quality of the product or service protected by the trademark [42] and will only be developed over time [11].

Extant literature has suggested trademarks as being more widely applicable than patents since their usefulness is not restricted primarily to manufacturing sectors (e.g. [35] [38] [43]). Furthermore, a major advantage of filing trademarks is that the application process is associated with less necessary resources. First, applying for a trademark is considerably cheaper than applying for a patent [38] [44]. Second, filing a trademark does not require a technological breakthrough like a patent [38] and the subsequent grant decision is less risky-meaning it is more likely to receive a grant decision for a trademark than for a patent. Patent eligibility requires that the underlying innovation is novel and non-obvious, whereas in the case of trademarks only the criterion of distinctiveness needs to be met [45]. These characteristics may make trademarks especially suitable for small firms.

Besides the lack of financial resources, their newness is a major challenge for startups [3]. New firms are usually unknown to potential customers and as a result, they often have to face a lack of trust in their new products or services [3]. Therefore, investing in marketing in order to finally start establishing identity and with it a brand seems to be pivotal to subsequent success [3]. In this process, trademarks can be regarded as fundamental for effective commercialization and diffusion of start-ups' innovations [11] [35].

Similar to patenting start-ups, trademarking start-ups exhibit several positive characteristics compared to their non-trademarking peers. Although literature on the interrelation of start-ups' trademarking behavior and their subsequent performance is relatively scarce, a positive effect of trademarking on survival [35] as well as on asset growth has been identified [33]. However, it is important to notice that trademarking only relates to subsequent performance as an indicator of innovation. This means, innovation leads to performance improvements-with trademarking being its measureand not the mere fact of trademarking alone.

\subsection{VCs and Their Influence on Start-Ups}

As indicated above, VCs are substantially involved in businesses of the companies they finance [11] [19] [46]. In order to increase the likelihood of success and rise their return on investment VCs take various measures-such as setting milestones [8] [11] [22] or staging capital injection [46] [47]. However, VCs do not merely monitor the businesses they finance, but they also provide advice and expertise [4] [10] [19] [12]. A rather broad body of research has investigated the potential benefits provided by VCs. For instance, [48] regards VCs as "value-added investors" that allocate benefits that excess the sole supply of financial resources. Rather they assist young firms in developing strate- 
gies [10] [11] [19]. By doing so, they provide support for making decisions regarding marketing [12], financing, budgeting and human resource (HR) issues [10]. Reference [3], for instance, regards especially insufficient marketing knowledge as major obstacle for the success of start-ups. Owing to their experience, VCs can usually compensate that lack of knowledge and set start-ups on the right track. Furthermore, VCs may speed up start-ups' development processes [19] and, hence, promote professionalization [22]. An evident sign for a start-up's professionalization progress is the recruitment of senior management [19]. Typically, venture-backed start-ups earlier recruit outside chief executive officers (CEOs) [22] which make the influence of VCs on the professionalization process apparent. Another indicator of start-ups' development stages is the launch of products on the market [3]. In this context, [19] had identified venture-financed start-ups as being faster in bringing products to the market

Besides the direct influence on start-ups' strategies, VCs have been found to provide further benefits. Due to their newness start-ups usually do not exhibit a sound level of reputation [3] [49] which is essential for establishing relationships with customers and suppliers in order to successfully achieve market entries [3] [50]. VCs can help to overcome this challenge by providing forms of certifications regarding the quality of the financed companies [8] [48] [49]. The importance of certification for start-ups has been demonstrated by, for instance, [49] who has shown that financing offers by VCs with high reputation are much more likely to be accepted by start-ups than offers from VCs with a lower degree of reputation. Another proof of VCs' certification effect and its relevance for start-ups is the increase of coorporative behavior after having received VC financing [50]. However, in the context of entering into cooperations, the intermediation function of VCs plays an equally important role. VCs often have large networks [4] [8] and consequently, can help start-ups find appropriate partners [26] [50]. Furthermore, VCs can help start-ups to acquire additional capital in later stages [46] [49]. A considerable avenue of research has also identified a positive correlation between receiving VC financing and subsequent performance. Start-ups being venture-backed have increased likelihoods of IPOs [50] as well as higher valuations at the time of IPOs [51]. Additionally, start-ups often exhibit a remarkable growth in size after receiving VC financing [52] [53].

\subsection{Patents and Trademarks in the Context of VC Financing}

Since this paper seeks to shed light on the changes in start-ups' patent and trademark portfolios after VC investments both literature on the role of patents and trademarks before and after VC investments have been investigated. The literature in this context can be divided into two major streams-the signaling value of patents and trademarks before $\mathrm{VC}$ financing and the influence of said investments on the underlying portfolios. As indicated above, start-ups face various obstacles when seeking external finance resulting from substantial information asymmetries between them and their potential financiers [1]. Since they cannot display major revenues [14] - especially in their early stages-VCs need to examine other factors that may indicate start-ups' expected values 
(see also [14] [54] [55]). One such indicator might be the scopes of start-ups' patent portfolios which hence, can be regarded as signals for their quality [14] [18] [54].

In signaling theory, a signal is sent by the better informed party-the start-up-to the less informed party - the VC [56] - resulting in a potential reduction of information asymmetries between those two parties [57]. In order for the sent information to be regarded as signal, two requirements need to be met-it has to be observable and costly [56]. The criterion of observability is obviously fulfilled both in the case of patent [29] and trademark filings. The requirement of the signal being costly is also met. The filing of patents is associated with direct costs of up to USD 20,000 [29] and various further costs of indirect nature-such as costs associated with the disclosure of information [27] [28] [29]. The filing of trademarks involves considerably less direct costs [38] [44]. Nevertheless, it is related with substantial further efforts since it requires careful thought about the desired perception of the firm by its consumers. Since start-ups in their early stages are not only unknown to capital providers but also to potential customers [3], they need to think even more carefully about the image their trademarks shall convey. Finally, the interpretation of a signal helps its receiver to draw conclusions about a characteristic which is difficult or impossible to observe [56] [57]. In the context of start-up financing, VCs can examine IP portfolios (the signal being the filing of IPRs) in order to deduce estimations of start-ups' expected values [14] [18] [20] [54].

Particular evidence for the relevance of patenting activity in reducing information asymmetries between start-ups and VCs is provided by [7] who have shown that patenting intensity increases with rising information asymmetry. Reference [18] has revealed similar interrelations. They have found the signaling value of patents as being greater in earlier funding rounds when information asymmetries are most incisive. Various studies regard patent activity as conveying information on the expected performance of start-ups [14] [18] [20] [54]. In order for an invention to be patentable three requirements need to be fulfilled: it needs to be new, non-obvious and useful [28]. The criterion of usefulness implies that there exists a market niche for the underlying innovation. Since a company will only file a patent in case they expect a positive grant decision, a company's decision to do so suggests that they have detected a market niche for their technology [58]. Additionally, [15] consider patents as reflecting the value of firms' technologies, meaning firms having technologies of higher qualities obtain more patents, and therefore are more attractive to potential investors. Moreover, being able to "stake technological claims" [59] — which is achieved by filing patents—can signal start-ups' future potential [59] which further supports the findings of [15]. Furthermore, [54] has underpinned the relevance of patents' signaling value for new ventures by revealing that start-ups decide to file for patents in order to signal their quality to potential investors. On the other hand, patents can also carry additional information other than those related to technological quality [58]. Such information can include the quality of start-ups' managements [9] [15] [58] and start-ups' stages of development [58].

A considerable body of research has succeeded to prove that the signaling function of 
patents is actually valued by VCs. First, patenting start-ups are more likely to receive VC funding. Reference [15] have conducted a study among U.S. software start-ups and found that patenting is positively related to the probability of receiving VC financing. Analyses of [14] [16] [17] [18] [19] have shown similar results, although in different settings regarding industry and region. Furthermore, patent filings have been found to positively affect the probability of attracting prominent VCs [18]. In addition, patenting activity influences the time to first VC funding. Patenting start-ups receive their first VC funding substantially earlier than their non-patenting peers [14] [19]. In this context, the number of patents as well as their quality positively affects the timing of first VC funding [14]. Finally, patenting activity has been identified as positively influencing the amount of VC financing [7] [9] [20].

Contrary to the signaling value of patents, there is no broad body of research on the signaling value of trademarks in VC financing. References [3] [60] and [61] have suggested that VCs positively value the market orientation of start-ups. Since trademarks are important means to protect marketing assets, the filing of those is likely to reveal information on start-ups' market orientation [62]. Reference [44] has further argued that trademarks are closely related to innovation in small firms, mainly due to substantially lower costs compared to patents making them more suitable for small firms (see also [38]). Taken together, one can argue that VCs value trademarks as signals for startups' technology quality and market readiness. However, to the best of our knowledge, only [21] have analyzed the signaling value of trademarks so far. They have found a positive relation between trademarks and subsequent valuation by VCs which provides support for the reasoning above.

The second relevant stream of literature addresses the converse case-meaning the influence of VCs on start-ups' patent and trademark portfolios. Only few researchers have examined these possible interrelations in the context of patenting. Reference [12] has investigated the patenting behavior of venture-backed U.S. start-ups across five manufacturing sectors. VC funding appears to positively influence patenting intensity, nevertheless, a slowdown in patenting during the first year after the funding round has been observed. However, they have primarily focused on the question if VC funding promotes innovation or if rather the opposite is the case. Furthermore, [10] has compared the patenting rates of 351 Italian venture-backed (33) and non-venture-backed start-ups (318) active in high-technology manufacturing industries and software between 1994 and 2003. According to their analysis, receiving VC funding is accompanied with a significantly higher propensity to patent. Furthermore, it leads to increased patenting intensity. However, it is important to recognize that the VC industry in Europe is still in its early stages-especially compared to the U.S. or Israel [10]. When additionally considering the small number of venture-backed start-ups in their sample, their findings may be only of limited informational value. Another study, focusing on the U.S., has been conducted by [13]. They have investigated the influence of VC funding on patented inventions by comparing 122 venture-backed and 408 non-venture-backed start-ups across twenty manufacturing industries between 1965 and 1992. However, 
they have prioritized the question whether VC funding promotes innovation and regarded increased patenting activity as the mere outcome of the same. Consequently, their findings have indicated a positive impact of VC financing on innovation. In fact, venture capital has been found to be 40 times as potent as $\mathrm{R} \& \mathrm{D}$. Furthermore, venture-backed firms are generally more likely to patent and their patents exhibit better qualities - with patent quality measured by citations. Nevertheless, further shedding light on the effect of VC funding on subsequent patenting activities of U.S. start-ups would be a noteworthy contribution to extant literature.

Regarding trademarks, there seems to be only one study investigating the impact of VC funding on start-ups' subsequent trademarking activity. The dataset of the study conducted by [11] consists of 4703 U.S. start-ups operating across six industries that filed their first IPR between 1998 and 2007. Their analysis has revealed that venturefinanced firms are more likely to file a trademark than a patent as first IPR.

However, there is, to the best of our knowledge, no study jointly examining the impact of $\mathrm{VC}$ funding on trademark and patent portfolios. Therefore, comparing trademark portfolios before and after VC financing is another important contribution to literature related to the interface between entrepreneurial financing and IP.

\section{Theory and Hypotheses}

\subsection{VC Investment and the Scope of a Start-Up's IP Portfolios}

Two major factors point to a rise in the number of patents filed after VC funding. The literature on the importance of patents as quality signals to VCs implies that start-ups already have obtained patents before first VC funding. Nevertheless, start-ups face challenges which probably hamper the filing of patents. First, start-ups often lack specific knowledge of the protection the IPR system can provide [63] which may prevent them from filing patents. Furthermore, they may lack both knowledge [18] and resources in form of capital and staff which are required to defend their patents [25] [33]. VCs, however, are usually able to provide support in terms of financial resources and legal knowledge for the filing and defending of start-ups' patents [9]. Second, extant literature suggests that VCs promote professionalization of the start-ups they finance [22]. Reference [22] has based professionalization on criteria such as formulation of HR policies and the recruitment of outsiders as CEOs. In contrast, we extend professionalization to the filing of IPRs. In case of patens, this assumption appears reasonable since the filing of these shows that firms have recognized the need to protect their technology in order to successfully master the challenges of launching new products and services. Taken together, we assume that VCs will promote the filing of IPRs in form of patents. Specifically, we expect a rise in the number of patent applications after a start-ups' first funding round.

Thus, the following hypothesis is formulated:

Hypothesis 1: The first funding round leads to an additional number of patent applications.

Regarding the filing of trademarks, we have similar assumptions. According to [60] 
[61], VCs regard marketing as crucial for the success of start-ups. In fact, they rank the importance of marketing higher than all other business functions. Since start-ups often lack sufficient experience exactly in that field [3], they need the expertise that VCs typically can provide. Furthermore, VCs set milestones related to the introduction of products and services on the market in order to shift start-ups' focus towards commercialization [11] [19] [22]. "Trademarks are an important tool in establishing the communicative link to consumers" [11] and therefore the filing of those can be regarded as one of the initial steps in the commercialization process of innovations. Since VCs aim at speeding up the commercialization of start-ups' products and services we shall argue that VC funding is accompanied by a rise in the number of trademark applications.

The following hypothesis is formulated accordingly:

Hypothesis 2: The first funding round leads to an additional number of trademark applications.

\subsection{VC Investment and the Composition of a Start-Up'S IP Portfolios}

We do not only expect a change in the scope of start-ups' IP portfolios after VC funding, but we also assume a change in their compositions-meaning the share of patents and trademarks within the portfolios. VCs usually have a limited time span devoted to each start-up within which they invest and then expect making first profits [4] [46] [64]. They usually decide to invest in ventures which they regard as being able to become profitable within reasonable time and with reasonable capital [8]. This implies that "VCs are not interested in funding basic research" [8]. Rather they aim at, as aforementioned, shifting start-ups' focus towards the commercialization of their innovations [11] [19]. This has been further confirmed by [22] who have found out that venture-backed start-ups have a significantly shorter time-to-market than their nonventure-backed peers. Since trademarks play an important role in the initial stages of the commercialization process, a considerable impact on the application of trademarks can be expected. We assume that VCs may promote the filing of trademarks as an initial step in the commercialization process more intensely than the filing of additional patents. Consequently, the share of trademark applications compared to patent applications in start-ups' IP portfolios after the first funding round should increase or, in other words, the number of additional trademark applications after the first funding round is expected to be higher than the number of additional patent applications.

This assumption is expressed in the following hypothesis:

Hypothesis 3: The first funding round leads to more additional trademark applications than additional patent applications.

\subsection{Effect of VC Investment and the Stage of the Venture Cycle}

Furthermore, we shall argue that the effects described in section 3.1 are observable throughout the whole venture cycle, although their intensities vary. In the underlying model, the progress through the venture cycle is approximated by the number of funding rounds. Reference [9] have, among other criteria, also used the number of funding 
rounds as proxy for the progress through the venture cycle, meaning with each subsequent funding round start-ups proceed along the venture cycle.

The relationship between VCs and the start-ups they finance is of ongoing nature, meaning that VCs usually invest repeatedly in the same start-up [47]. Consequently, they continuously monitor and advise the management, among others, on IP issues. We therefore assume that each funding round has an impact on the numbers of patent and trademark applications-meaning a supplementary funding round results in additional applications of patents and trademarks. However, we further expect that these effects will vary when start-ups proceed along the venture cycle.

As aforementioned, VCs provide support in terms of expertise and capital for the filing of patents in order to protect a start-up's existing technology base [9] [12] and promote start-ups' professionalization [22]. However, we do not expect them to particularly aim at enhancing further $\mathrm{R} \& \mathrm{D}$ resulting in additional patentable technologies which is similar to the assumptions of [8]. Furthermore, the signaling value of filing patent applications decreases once start-ups have succeeded in attracting VC funding. Even in the case of further capital requirements, the signaling value is expected to play a minor role since VCs can usually provide support here [46] [49]. Taken together, we expect the number of additional patent applications after subsequent funding rounds to decrease along the venture cycle.

This expectation leads to the following hypothesis:

Hypothesis 4: The number of additional patent applications decreases with the startups' progress through the venture cycle.

Regarding the number of additional trademark applications, we have different expectations. As start-ups proceed along the venture cycle they leave the phase of developing new technologies and approach the commercialization of their products or services. As abovementioned, VCs purpose shifting the start-ups' focus towards the commercialization of their innovations [11] [19], which further promotes this process. Since trademarks are essential components within this development, there is reason to presume that VCs aim at enhancing start-ups trademarking activities while they proceed along the venture cycle. Hence, we assume that the number of additional trademark applications increases with each subsequent funding round.

The following hypothesis should thus hold:

Hypothesis 5: The number of additional trademark applications increases with the start-ups' progress through the venture cycle.

\section{Data and Method}

\subsection{Data}

The dataset for this analysis has been obtained from several sources. Investment data of VC-funded start-ups has been acquired from the VentureXpert database (see also e.g. [7] [9] [15] [11]). Since this study is focused on the U.S. the data on trademark applications has been collected from the United States Patent and Trademark Office (USPTO). U.S. patent data has been gathered from the EPO Worldwide Patent Statistical Database 
(also known as PATSTAT). Then, patent and trademark portfolios have been created using a manual matching process based on the start-ups' names.

Initially, 50,477 funding rounds of 26,209 U.S. ${ }^{1}$-based venture-backed ${ }^{2}$ start-ups have been retrieved from VentureXpert. The VentureXpert database does not provide any information on companies' stages within the venture cycle. However, the exclusion of observations with funding round numbers greater than three seemed to be an appropriate way to ensure a focus on start-ups only. Cases with missing start-up founding dates have been dropped. ${ }^{3}$ Likewise, funding rounds with incomplete investor data have been excluded. ${ }^{4}$ Furthermore, funding rounds which featured probable inconsistencies regarding round date information have been deleted. These include observations with more than one round date for the same funding round of a company as well as cases in which funding has been acquired before a start-up's founding date or rounds which are reported as having occurred after subsequent rounds. Finally, cases in which funding occurred more than ten years after a start-ups founding date ${ }^{5}$ have been dropped. ${ }^{6}$ These modifications lead to a dataset comprising 24,387 funding rounds of 13,896 U.S. venture-backed start-ups.

In the next step, the data on patents and trademarks ${ }^{7}$ have been adjusted. Since the trademark dataset has been retrieved from the USPTO it only covers U.S. trademarks. In order to preserve consistency, patent data has been restricted to the U.S. as well. Finally, the patent and trademark portfolios have been compiled in a manual matching process based on the start-ups' names. In order to improve the measurability of VC funding on subsequent IP activities, only start-ups that have proven to be generally affine to applying for patents and trademarks have been examined. This means, only companies that applied for at least one patent and one trademark during the time of observation $^{8}$ have been kept within the dataset. ${ }^{9}$ Hence, the underlying dataset comprises patent and trademark portfolios for 531 start-ups that received in total 1062 funding rounds between 1991 and 2009.

\subsection{Operationalization Variables}

The two dependent variables of this regression analysis are the additional numbers of patent and trademark applications filed after VC funding rounds-new patent applica-

${ }^{1}$ Start-ups for which more than one region is available have been excluded. During this process, also start-ups with missing company name have been deleted.

${ }^{2}$ Funding rounds where the investor type is categorized as "Private Equity Firm" (84.56\%), "Corporate PE/ Venture" (12.76\%) or "SBIC" (2.68\%) have been kept within the dataset. SBICs (Small Business Investment Company) are privately owned funds that make investments in U.S. small companies.

${ }^{3}$ These cases comprise $15.39 \%$ of the initial number of funding rounds.

${ }^{4}$ Here, the investor name, founding date or funding amount are missing or the investor firm is founded after the correspondent funding round (29.76\% of rounds of initial dataset).

${ }^{5}$ In these cases, it is likely that data from different companies were merged (following [47]).

${ }^{6}$ These inconsistent cases comprise $6.54 \%$ of all initial funding rounds.

${ }^{7}$ Trademark applications without filing dates (156 or $0.10 \%$ ) or invalid Nice classification (47 or $0.03 \%$ ) have been excluded.

${ }^{8}$ The relevant timeframe is between 24 months before the first and 24 months after the third funding round.

${ }^{9}$ Additionally, one company needed to be excluded since its very high number of patent applications seemed rather suspect. 
tions after round and new trademark applications after round. Using patent applications rather than grants is widely spread in research on IP activity (e.g. [11] [13] [18]) since "they relate to the point in time at which the start-up made the strategic decision to obtain a specific type of IP" [11]. Moreover, ultimate patent grant decisions have been frequently reported as being of little importance in the context of VC funding (e.g. [7] [14] [15]). Likewise, we also focus on trademark applications rather than registrations. In the further analysis of the quality of the newly filed patents a different dependent variable is used-new citation-weighted patents after round. This variable measures the number of citations the newly filed patents accumulative receive.

The major independent variables are binary variables for each funding roundround 1 dummy, round 2 dummy and round 3 dummy which equal one for round one, round two or round three respectively and otherwise 0 . Furthermore, the number of patent and trademark applications before funding rounds are included-patent applications before round and trademark applications before round. Patent and trademark applications which are more than five years before a start-up's founding date have not been counted. ${ }^{10}$ Additionally, a patent dummy variable and a trademark dummy variable are used. These allow distinguishing the effects of VC funding on the number of additional patent and trademark applications for start-ups that have not applied for any patents or trademarks prior to first funding from those having filed at least one application. Similar variables have been created for the above mentioned investigation of patent citations. Citation-weighted patents before round counts the number of citations of those patent applications that were filed before funding rounds. The citations dummy distinguishes start-ups whose patents ${ }^{11}$ before first funding have no citations from those start-ups whose patents have. Additionally, the variables patent literature backward references and non-patent literature backward references represent the number of backward references in patent and non-patent literature, respectively.

The following control variables are included in the regression analysis. Start-up age (see also [11] [18] [21]) represents the age in years of start-ups at funding. There is reason to assume that older start-ups already are further developed within their business cycle and therefore differ in their IP portfolios [65]. In order to control for differences in VC characteristics and influence, the number of investors of a particular funding round is included. $V C$ age measures the time in years between a VC's first investment and the date of the current funding round (see also e.g. [21]). VC experience counts the number of investments a VC already has undertaken prior to the current funding round (see also e.g. [21]). In case more than one VC invests in a specific funding round, the average values for age and experience are calculated. Furthermore, we control for the amount of funding. Since the underlying data does not provide information on the amount that a particular VC invests in a specific funding round, the amount that a VC invests in total in a start-up-total amount invested in start-up by VC is used

\footnotetext{
${ }^{10}$ There is reason to assume that patent and trademark applications which were filed more than five years before a company's founding date are hardly, if at all, related to the current business of the company. Alternatively, IP portfolios of different companies could have been merged.

${ }^{11}$ Patents refers to patent applications in this context.
} 
instead. Again, in the case of a syndicate the mean value is calculated. Finally, six industry and six U.S. region dummies (see also e.g. [11] [21]) are included in order to capture differences across industries [16] [25] [31] and regions. An overview of all variables of the regression is provided in Table 1.

Table 1. Definition of variables.

\section{Variable}

\section{Dependent variables}

New patent applications after round

New citation-weighted patents after round

New trademark applications after round

\section{Independent variables}

\section{Intellectual property characteristics}

Patent applications before round

Patent dummy

Citation-weighted patents before round

Citations dummy

Patent literature bwd. references

Non-patent literature bwd. references

Trademark applications before round

Trademark dummy

\section{Investment characteristics}

Round 1 dummy

Round 2 dummy

Round 3 dummy

Number of VCs investing in round

Total amount invested in start-up by VC

\section{Investor Characteristics}

VC age

VC experience

\section{Start-up Characteristics}

Start-up age

Start-up industry dummies

Start-up region dummies

\section{Description}

Number of additional U.S. patent applications after funding round (patent applications between $12^{\star}\left(24^{\star *}\right)$ months before and 12 (24) months after funding round are counted); ${ }^{\star} \mathrm{M} 1,{ }^{* *} \mathrm{M} 3$

Number of (three years forward) citations of new U.S. patent applications after funding round.

Number of additional U.S. trademark applications after funding round (trademark applications between $12^{*}$ $\left(24^{\star *}\right)$ months before and 12 (24) months after funding round are counted); ${ }^{\star} \mathrm{M} 2,{ }^{* *} \mathrm{M} 4$

U.S. patent applications that a start-up filed before a round

Allows distinguishing between start-ups that have not applied for any U.S. patents prior to first funding $(=0)$ from those that have

Number of (three years forward) citations of U.S. patent applications filed before funding round

Allows distinguishing between start-ups who have no patents cited prior to first funding round $(=0)$ from those that have

Number of backward references in patent literature of U.S. patent applications filed before funding round Number of backward references in non-patent literature of U.S. patent applications filed before funding round

U.S. trademark applications that a start-up filed before a round

Allows distinguishing between start-ups that have not applied for any U.S. trademarks prior to first funding $(=0)$ from those that have

Refers to the number of funding rounds, Equals 1 for first funding rounds, 0 otherwise Refers to the number of funding rounds, Equals 1 for second funding rounds, 0 otherwise Refers to the number of funding rounds, Equals 1 for third funding rounds, 0 otherwise

Number of VCs investing in a funding round

Total amount of funding in USD provided by a VC

throughout all rounds. In case of multiple VCs in one round the average is used

Time in years between a VC's first investment in its company history and focal funding round date. In case of multiple VCs in one round the average is used

Counts number of investments a VC already has undertaken prior to funding round date. In case of multiple $\mathrm{VCs}$ in one round the average is used

Age of start-up at funding round date (in years)

Six variables to distinguish between start-ups' industries:

"Biotechnology", "Computer Software and Services", "Communications and Media", "Medical/Health", "Semiconductors/Other Elect" and "Other"

Six variables to distinguish between start-ups' regions: "N. California", "New England”, "New York Tri-State", "S. California", "Southwest" and "Other" 


\subsection{Event Analysis}

This paper uses an event study to perform the underlying analysis (see also e.g. [66]). An event study is usually applied to "see whether a particular event influences some outcome" [67] and therefore appears most appropriate for investigating the influence of VC funding-being the event-on start-ups' IP portfolios-being the outcome. More precisely, the number of new patent and trademark applications after VC funding rounds is determined by comparing the stock of patent and trademark applications before and after VC funding rounds. The number of applications before funding rounds is assessed at the point in time $12^{12}$ months prior to the round date. The number of new applications after funding rounds comprises applications filed between the timeframe of 12 months before and 12 months after the round date. Figure 1 exemplarily illustrates the assessment of patent applications for the 12 months' timeframe.

\section{Results and Discussion}

\subsection{Descriptive Results}

The final dataset comprises 1062 funding rounds of 531 start-ups with their corresponding patent and trademark portfolios. $35.2 \%$ of the observations relate to the first funding round, $36.0 \%{ }^{13}$ and $28.8 \%$ to round two and three respectively. Furthermore, funding rounds refer to start-ups of the following industries: medical/health (25.0\%), computer software and services (19.6\%), biotechnology (12.6), communications and

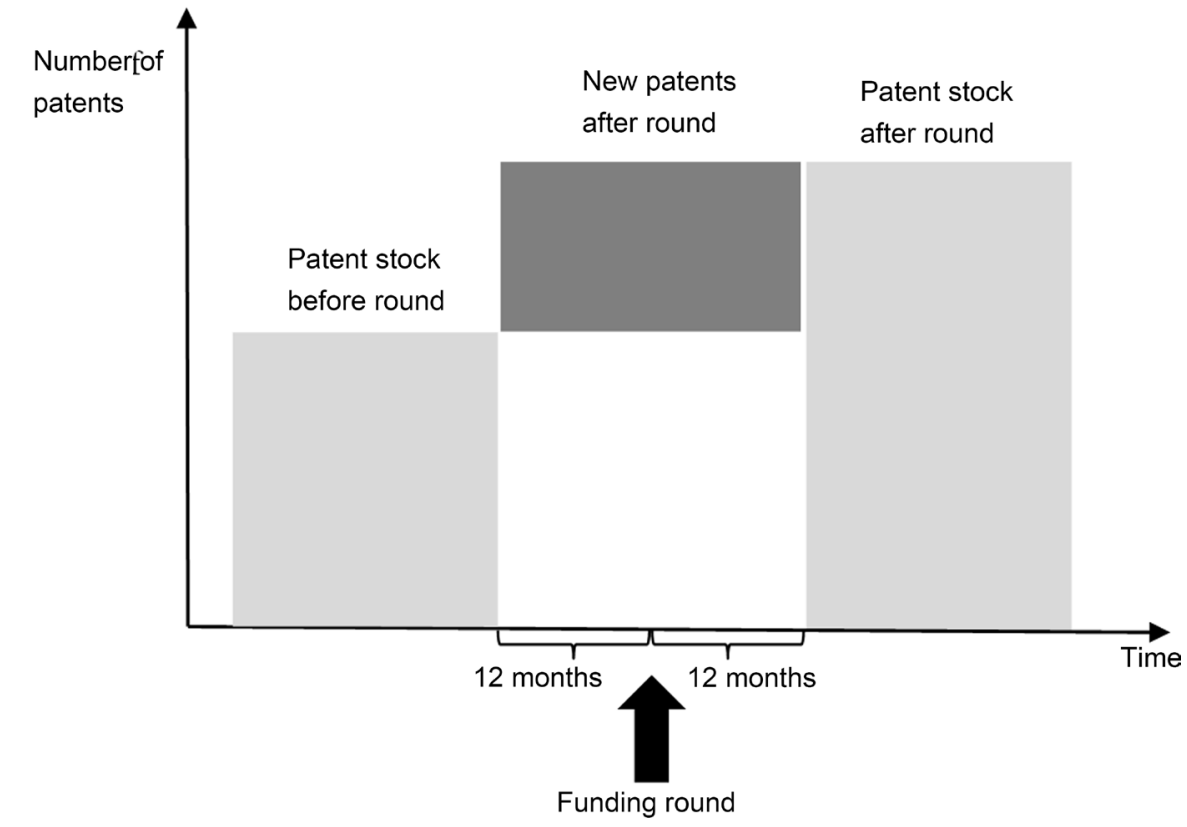

Note: Patents refers to patent applications

Figure 1. Assessment of new patent applications after funding round.

\footnotetext{
${ }^{12}$ In M1 and M2 a twelve months' timeframe whereas in M3 and M4 a 24 months' timeframe is used.

${ }^{13}$ The higher proportion of second rounds compared to first rounds results from start-ups that have obtained capital from sources other than VCs prior to their first VC funding round.
} 
media (11.5\%), semiconductors/other elect (11.0\%), and other industries (20.3\%). The mean value for start-up age at funding is 2.9 years (median: 2.4 ) implying that most of them are still at early stages of their operations. The results of [18] in a similar study have revealed a higher age at funding (mean: 4.06) which is probably owed to the fact that we only include the first three funding rounds in the analysis. On average, the syndicate per round (number of VCs investing in round) comprises 2.2 investors and has an averaged age ( $V C$ age) of nine years as well as undertaken 223 financing deals prior to funding round ( $V C$ experience). The mean value for the total amount invested in start-up by $V C$ is USD 9.4 million.

The variable patent dummy ${ }^{14}$ indicates that start-ups already acquire at least one patent prior to first funding in $18.5 \%$ of the cases. For instance, also [10] have found that the majority of start-ups do not apply for patents before the entry of VCs. The highest proportion of start-ups that patent prior to first funding is found in the biotechnology industry (23.9\%). Previous studies have identified venture-backed start-ups active in this industry as considerably affine to patenting [16]. This appears to be in accordance with the findings of this study when comparing the proportion with other industries. Generally, the proportion is rather low. The mean number of patent applications before round is 8.7 (median: 1). Minimum (0), maximum (303) and standard deviation (24.0) suggest a fairly high variance in start-ups' patent strategies ${ }^{15}$. Interestingly, the computer software and service industry features the highest mean value (12.7). Preceding analyses have suggested that patents for companies of this industry are of little value [16] [43] - at least before they approach the stage of generating revenues [9]. Firms of this sample, however, might not necessarily have reached this stage yet. The variable new patent applications after round show a slightly lower, but still high level of variance. A mean value of 5.8 and a maximum of 225 patents indicate a pronounced influence of VC funding on subsequent patenting activity. Again, the results are contrary to previous findings regarding the importance of patenting in the software industry. The underlying data suggest a high maximum (171) and considerable great mean (6.7) for the number of new patent applications after funding round in this industry.

In contrast, trademarking activity appears to be more homogenous among the investigated start-ups. Generally, mean (1.8), minimum (0), maximum (28) and standard deviation (3.2) of trademark applications before round show lower values implying that the distribution of trademarks before funding is less dispersed compared to patents. For instance, [21] have also found start-ups' trademarking strategies being less diverse than patenting strategies. Start-ups operating in the communication and media industry demonstrate the highest mean value for this variable (2.6) as well as for new trademark applications after round (4.9) which appears natural to assume considering previous analyses. Reference [11] has aimed at answering a slightly different research question, but nevertheless their results have proven the high relevance of trademarks in this in-

${ }^{14}$ Descriptive results of patent and trademark variables in this subchapter refer to the twelve months models M1 and M2.

${ }^{15}$ See also [9] for the skewness of patent portfolios. 
dustry. The values for new trademark applications after round across all industries (mean: 3.3, median: 2, min: 0; max: 84, standard deviation: 5.9) also characterize trademarking activity as less distorted. Besides, extant literature has suggested that trademarks are more widely applicable than patents (e.g. [35] [43] [38]). However, the results of this study suppose that patents are more important. Mean values for both applications before and new applications after round are higher in the case of patents. Furthermore, the variable trademark dummy reports that only $10.0 \%$ of start-ups obtain trademarks before first funding which does not lend support for the assumption that trademarks are more deployable than patents. An overview of descriptive results can be found in Table 2 and Table 3.

Table 2. Descriptive statistics-intellectual property characteristics.

\begin{tabular}{|c|c|c|c|c|c|}
\hline & Mean & S.D. & Median & Min. & Max. \\
\hline \multicolumn{6}{|l|}{ Intellectual property characteristics } \\
\hline \multicolumn{6}{|l|}{12 months model } \\
\hline New patent applications after round & 5.8 & 19.6 & 0 & 0 & 225 \\
\hline Patent applications before round & 8.7 & 24.0 & 1 & 0 & 303 \\
\hline Patent dummy (in \%) & 18.5 & & 0 & 0 & 1 \\
\hline New citation-weighted patents after round & 158.5 & 2435.1 & 0 & 0 & 55,653 \\
\hline Citation-weighted patents before round & 68.0 & 320.4 & 0 & 0 & 6808 \\
\hline Citations dummy (in \%) & 15.4 & & 0 & 0 & 1 \\
\hline Patent literature bwd. references & 482.1 & 3258.1 & 0 & 0 & 62,300 \\
\hline Non-patent literature bwd. references & 943.2 & $11,187.4$ & 0 & 0 & 244,923 \\
\hline New trademark applications after round & 3.3 & 5.9 & 2 & 0 & 84 \\
\hline Trademark applications before round & 1.8 & 3.2 & 0 & 0 & 28 \\
\hline Trademark dummy (in \%) & 10.0 & & 0 & 0 & 1 \\
\hline \multicolumn{6}{|l|}{24 months model } \\
\hline New patent applications after round & 11.3 & 29.6 & 2 & 0 & 278 \\
\hline Patent applications before round & 6.0 & 18.1 & 0 & 0 & 193 \\
\hline Patent dummy (in \%) & 13.5 & & 0 & 0 & 1 \\
\hline New citation-weighted patents after round & 202.7 & 2460.4 & 1 & 0 & 55,938 \\
\hline Citation-weighted patents before round & 43.5 & 262.4 & 0 & 0 & 6808 \\
\hline Citations dummy (in \%) & 11.6 & & 0 & 0 & 1 \\
\hline Patent literature bwd. references & 320.5 & 2623.8 & 0 & 0 & 62,300 \\
\hline Non-patent literature bwd. references & 690.6 & $10,123.3$ & 0 & 0 & 232,779 \\
\hline New trademark applications after round & 5.8 & 9.2 & 3 & 0 & 118 \\
\hline Trademark applications before round & 0.9 & 2.1 & 0 & 0 & 19 \\
\hline Trademark dummy (in \%) & 6.5 & & 0 & 0 & 1 \\
\hline
\end{tabular}


Table 3. Descriptive statistics-investment, investor and start-up characteristics.

\begin{tabular}{|c|c|c|c|c|c|}
\hline & Mean & S.D. & Median & Min. & Max. \\
\hline \multicolumn{6}{|l|}{ Investment characteristics } \\
\hline Round 1 dummy & 35.2 & & 0 & 0 & 1 \\
\hline Round 2 dummy & 36.0 & & 0 & 0 & 1 \\
\hline Round 3 dummy & 28.8 & & 0 & 0 & 1 \\
\hline Number of VCs investing in round & 2.2 & 1.4 & 2 & 1 & 8 \\
\hline Total amount invested in start-up by VC & 9.4 & 10.1 & 7.1 & 0.03 & 138.7 \\
\hline \multicolumn{6}{|l|}{ Investor characteristics } \\
\hline VC age & 9.0 & 4.9 & 8.9 & 0 & 21.9 \\
\hline VC experience & 223.1 & 264.6 & 141.6 & 0 & 2281.0 \\
\hline \multicolumn{6}{|l|}{ Start-up characteristics } \\
\hline Start-up age & 2.9 & 2.2 & 2.4 & 0 & 10 \\
\hline \multicolumn{6}{|l|}{ Start-up industry (in \%) } \\
\hline Medical/health & 25.0 & & 0 & 0 & 1 \\
\hline Computer software and serv. & 19.6 & & 0 & 0 & 1 \\
\hline Biotechnology & 12.6 & & 0 & 0 & 1 \\
\hline Communications and media & 11.5 & & 0 & 0 & 1 \\
\hline Semiconductors/other elect. & 11.0 & & 0 & 0 & 1 \\
\hline Other & 20.3 & & 0 & 0 & 1 \\
\hline \multicolumn{6}{|l|}{ Start-up region (in \%) } \\
\hline N. California & 33.1 & & 0 & 0 & 1 \\
\hline New England & 15.4 & & 0 & 0 & 1 \\
\hline S. California & 13.6 & & 0 & 0 & 1 \\
\hline New York Tri-State & 8.0 & & 0 & 0 & 1 \\
\hline Southwest & 5.9 & & 0 & 0 & 1 \\
\hline Other & 24.0 & & 0 & 0 & 1 \\
\hline
\end{tabular}

Notes: $\mathrm{N}=1062$ observations of 531 start-ups that received VC funding between 1991 and 2009. Data sources: VC data from VentureXpert, patent data from PATSTAT, trademark data from USPTO.

\subsection{Multivariate Results}

The results of the multivariate analysis for M1 and M2 are first tested using a t-test before further verified through OLS regression. Table 4 summarizes the results of the t-test. The mean value for the number of new patent applications after round for first funding rounds is 6.3. Regarding hypothesis 1, the t-test shows that the null hypothesis-first funding rounds do not have a significant effect on the number of new patent applications-can be rejected ( $\mathrm{p}<0.001)$. Likewise, the results deliver strong support for hypothesis 2 which assumes a rise in the number of trademarks after first funding 
Table 4. VC funding and additional patent and trademark applications in 12 months model.

\begin{tabular}{|c|c|c|c|c|c|}
\hline & & \multicolumn{2}{|c|}{ New patents ${ }^{a}$ after round } & \multicolumn{2}{|c|}{ New trademarks ${ }^{a}$ after round } \\
\hline & & Mean & S.D. & Mean & S.D. \\
\hline & Round 1 & 6.3 & 20.9 & 2.8 & 4.9 \\
\hline & Round 2 & 5.8 & 19.3 & 3.7 & 6.9 \\
\hline & Round 3 & 5.4 & 18.6 & 3.3 & 5.6 \\
\hline & & p-value & t-value & & \\
\hline Hypothesis 1 & New patents after round & 0.000 & $5.810^{\star * *}$ & & \\
\hline Hypothesis 2 & New trademarks after round & 0.000 & $10.998^{* * *}$ & & \\
\hline Hypothesis 3 & New patents vs. new patents & 0.999 & -3.117 & & \\
\hline \multirow[t]{3}{*}{ Hypothesis 4} & New patents after round & & & & \\
\hline & Round 1 vs. round 2 & 0.381 & 0.303 & & \\
\hline & Round 2 vs. round 3 & 0.380 & 0.307 & & \\
\hline \multirow[t]{3}{*}{ Hypothesis 5} & \multicolumn{2}{|c|}{ New trademarks after round } & & & \\
\hline & Round 1 vs. round 2 & 0.0179 & $-2.102^{*}$ & & \\
\hline & Round 2 vs. round 3 & 0.7906 & 0.809 & & \\
\hline
\end{tabular}

Notes: $\mathrm{N}=1062$ observations of 531 start-ups that received VC funding between 1991 and 2009; Data sources: VC data from VentureXpert, patent data from PATSTAT, trademark data from USPTO; ${ }^{*} \mathrm{p}<0.05,{ }^{* *} \mathrm{p}<0.01,{ }^{* *} \mathrm{p}<$ 0.001 ; ${ }^{\mathrm{N}} \mathrm{New}$ patents and new trademarks refer to new patent and trademark applications.

rounds. The mean value the new trademark applications after round for first rounds is 2.8 and statistically significant $(\mathrm{p}<0.001)$. Since the mean for the number of new applications is considerably higher for patents (6.3) than for trademarks (2.8) it can be assumed that hypothesis 3 does not hold. The performed comparison of the two means confirms this assumption and suggests that rather the opposite is the case. Furthermore, $\mathrm{t}$-tests are applied to investigate the impact of $\mathrm{VC}$ funding on additional patent (H4) and trademark applications (H5) along the venture cycle. The mean values for new patent applications after round are 6.3 for first, 5.8 for second and 5.4 for third rounds. This may appear as support for a decreasing number of new patent applications with the start-up's progress along the venture cycle (H4). However, the results of the t-test do not allow rejecting the null hypothesis in both cases and therefore do not provide support for hypothesis 4 . The findings for hypothesis 5 are mixed. The number of new trademark applications after round shows mean values of 2.8, 3.7 and 3.3 for first, second and third rounds respectively. Regarding the comparison between first and second rounds the null hypothesis can be rejected $(\mathrm{p}<0.05)$. However, the results do not suggest a significantly higher effect of third rounds on trademarking activity compared to second rounds. Taken together, hypothesis 5 is only partly supported, meaning that the number of additional trademarks filed rises from first to second rounds, but not from second two third rounds. 
The results of the t-test are further investigated in an OLS regression. In order to compensate for the skewed distributions of the dependent variables-new patent applications after round and new trademark applications after round-the natural logs of these variables are used instead. The following equation estimates the number of new patent applications after round for firm $i$ in round $t .^{16}$

$\log (\text { New patents after round })_{i t}=$

$\beta_{0}+\beta_{1}$ (Patents before round P $\left._{\mathrm{t}}\right)+\beta_{2}\left(\right.$ Patent dummy $\left._{\mathrm{t}}\right)+$

$\beta_{3}\left(\right.$ Trademarks before round $\left._{\mathrm{t}}\right)+\beta_{4}\left(\right.$ Trademark dummy $\left._{\mathrm{t}}\right)+$

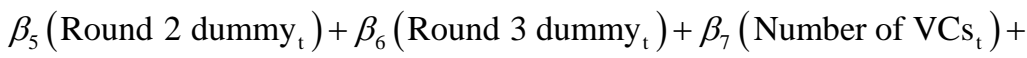

$\beta_{8}\left(\right.$ Amount invested $\left._{\mathrm{t}}\right)+\beta_{9}\left(\mathrm{VC}_{\text {age }}\right)+\beta_{10}\left(\right.$ VC experience $\left._{\mathrm{t}}\right)+$

$\beta_{j}\left(\right.$ Industry dummies $\left._{\mathrm{j}}\right)+\beta_{\mathrm{k}}\left(\right.$ Region dummies $\left._{\mathrm{k}}\right)+\varepsilon$.

Table 5 summarizes the results for the 12 months' timeframe (M1 and M2). In the underlying regression, first rounds are used as reference group. This implicates that the effect of second and third rounds is estimated relative to the effect of first rounds. More specifically, this means that the constant of the regression estimates the effect of first rounds, whereas the effect of second and third rounds is the sum of the constant's value and the coefficient of the round 2 dummy or the round 3 dummy, respectively. The reported results of M1 suggest a strong influence of first funding rounds on subsequent patenting activity, with an increase of $80.5 \%$ of the patent portfolio ( $\mathrm{p}<0.001)$. Hypothesis 1 is thus confirmed. When including the patent dummy for first funding rounds, the estimated effect decreases. This implies that start-ups that already had acquired at least one patent prior to first funding only feature an increase of $48,6 \%$ in their patent portfolio $(\mathrm{p}<0.01)$. This may indicate that the influence of VC funding is smaller for start-ups that already had recognized themselves the need for protecting their technological knowledge prior to first funding.

M2 investigates the effect of first funding on consecutive trademarking activity and delivers strong support for hypothesis 2 . The value of the constant estimates an increase in start-ups' trademark portfolios of $71.1 \%$ after first rounds ( $p<0.001$ ). Contrary to the case of patents, the trademark dummy does not show a significant impact which indicates that whether having or not at least one trademark prior to first funding is largely irrelevant for subsequent trademarking.

When comparing the values of the constants in M1 and M2, support for hypothesis 3 $(\mathrm{p}<0.001)$ cannot be found. As above mentioned, the relative growth from first rounds

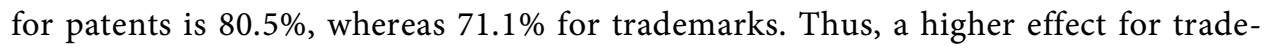
marking activity cannot be detected which is also in accordance with the previously

\footnotetext{
${ }^{16}$ Notes: Patents refers to patent applications. Since the effect of VC funding is estimated relative to effect of first rounds, the round 1 dummy is not included in the equation (see explanation in following paragraph). The number of new trademark applications after round is estimated analogously-only the dependent variable is replaced accordingly. Region dummies comprise the following dummy variables: "New England", "S. California", "New York Tri-State", "Southwest", and "Other". Industry dummies include dummy variables for: "Computer software and serv.", "Biotechnology", "Communications and media", and "Semiconductors/other elect.".
} 
Table 5. VC funding and additional patent and trademark applications in 12 months model.

\begin{tabular}{|c|c|c|}
\hline Dependent variable: & $\begin{array}{c}\text { Log (new patents after } \\
\text { round })\end{array}$ & $\begin{array}{c}\text { Log (new trademarks after } \\
\text { round) }\end{array}$ \\
\hline & M1 & M2 \\
\hline \multicolumn{3}{|l|}{ Independent variables } \\
\hline \multicolumn{3}{|l|}{ Intellectual property characteristics } \\
\hline \multirow[t]{2}{*}{ Patent applications before round } & $0.012^{* * *}$ & $0.002^{*}$ \\
\hline & $(0.000)$ & $(0.039)$ \\
\hline \multirow[t]{2}{*}{ Patent dummy } & $-0.319^{* *}$ & 0.004 \\
\hline & $(0.007)$ & $(0.962)$ \\
\hline \multirow[t]{2}{*}{ Trademark applications before round } & 0.018 & $0.032^{* *}$ \\
\hline & $(0.224)$ & $(0.002)$ \\
\hline \multirow[t]{2}{*}{ Trademark dummy } & 0.258 & 0.084 \\
\hline & $(0.073)$ & $(0.363)$ \\
\hline \multicolumn{3}{|l|}{ Investment characteristics } \\
\hline \multirow[t]{2}{*}{ Constant } & $0.805^{\star * *}$ & $0.711^{* * *}$ \\
\hline & $(0.000)$ & $(0.000)$ \\
\hline \multirow[t]{2}{*}{ Round 2 dummy } & 0.043 & $0.212^{\star *}$ \\
\hline & $(0.681)$ & $(0.003)$ \\
\hline \multirow[t]{2}{*}{ Round 3 dummy } & 0.051 & 0.097 \\
\hline & $(0.690)$ & $(0.272)$ \\
\hline \multirow[t]{2}{*}{ Number of investors } & -0.043 & $0.043^{*}$ \\
\hline & $(0.141)$ & $(0.027)$ \\
\hline \multirow[t]{2}{*}{ Total amount invested by VC } & 0.000 & $0.010^{* *}$ \\
\hline & $(0.969)$ & $(0.005)$ \\
\hline \multicolumn{3}{|l|}{ Investor Characteristics } \\
\hline \multirow[t]{2}{*}{ VC age } & -0.013 & -0.013 \\
\hline & $(0.275)$ & $(0.129)$ \\
\hline \multirow[t]{2}{*}{ VC experience } & 0.000 & 0.000 \\
\hline & $(0.559)$ & $(0.540)$ \\
\hline \multicolumn{3}{|l|}{ Start-up Characteristics } \\
\hline \multirow[t]{2}{*}{ Start-up age } & -0.023 & -0.024 \\
\hline & $(0.299)$ & $(0.123)$ \\
\hline Start-up industry dummies (6 cat.) & Yes & Yes \\
\hline Start-up region dummies (6 cat.) & Yes & Yes \\
\hline $\mathrm{N}$ funding rounds & 1062 & 1062 \\
\hline $\mathrm{N}$ start-ups & 531 & 531 \\
\hline F value & 2.37 & 3.68 \\
\hline R-squared & 0.082 & 0.078 \\
\hline
\end{tabular}

Notes: p-values in parentheses. Reference round number: "round 1"; reference industry: "Medical/health"; reference region: "N. California". Data sources: VC data from VentureXpert, patent data from PATSTAT, trademark data from USPTO. ${ }^{a} \mathrm{New}$ patents and new trademarks refer to new patent and trademark applications. ${ }^{*} \mathrm{p}<0.05,{ }^{* *} \mathrm{p}<$ $0.01,{ }^{* * *} \mathrm{p}<0.001$. 
performed t-test.

Furthermore, we expect a decreasing number of new patent applications after funding with the progress along the venture cycle. The estimated effects for second and third rounds are not significant on the $95 \%$ confidence level. This means, the growth of the patent portfolio after second and third rounds does not differ from the effect resulting from first rounds. In other words, the relative growth will be $80.5 \%$ in all three cases. Consequently, there exists no decreasing effect of patenting activity along the venture cycle and hypothesis 4 is rejected.

Finally, M2 is used to test hypothesis 5 which assumes a rise in the number of additional trademark filings with each subsequent funding round. The relative growth of the trademark portfolio after first rounds is $71.1 \%(\mathrm{p}<0.001)$. The coefficient of the round 2 dummy suggests that the growth of the portfolio is $21.2 \%(\mathrm{p}<0.01)$ higher compared to first rounds and thus, a cumulative growth by $92.3 \%$ ( $71.1 \%$ plus $21.2 \%$ ) after second rounds is estimated. This seems to lend tentative support for hypothesis 5 . However, when examining the effect of third rounds, we cannot presume a significant effect. This means the portfolio grows by $71.1 \%$ after third rounds which are not higher than the effect of second rounds. Although, the results for second rounds are in favor of hypothesis 5, it eventually has to be rejected due to the non-existent additional effect of third rounds. These findings have already been predicted by the t-test.

Interestingly, the effect of start-up age is not significant in both models. This may imply that the influence of VCs on subsequent IP activity is dependent on the stage of the start-up within the venture cycle-which is approximated by the number of funding rounds (see also [9]) - rather than on the actual age. For M2, the results report a significant effect of the total amount invested by $V C$ in a start-up $(\mathrm{p}<0.01)$. However, with a coefficient indicating an additional growth of $1 \%$ resulting from one additional million USD invested this effect seems negligible. The findings for the number of investors are similar. An additive growth of $4.3 \%(\mathrm{p}<0.05)$ caused by one additional investor is rather small and also only exists in M2. Additionally, a differing impact due to VC age and experience is not observable in both models.

\section{Conclusions}

In this paper, the impact of VC funding on start-ups' subsequent patent and trademark strategies has been investigated. For this purpose, patent and trademark applications before and after funding rounds of 531 U.S. start-ups have been compared. The results show that VC funding plays an important role, meaning that it does indeed cause a change in start-ups' IP strategies. The findings add to the literature on start-ups' IP portfolios. Specifically, they contribute to a deeper understanding of the interface between VC funding and IP portfolios [10] [11] [12] [13].

First, this paper contributes to the body of research on the influence of VCs on start-ups' patenting activities [10] [12] [13]. The applied event study delivers evidence for a significant impact of VC funding on subsequent patenting strategy. First, second and third funding rounds are associated with a growth of start-ups' patent portfolios. 
Earlier analyses (see e.g. [10]) raised concerns regarding the question whether the effect on subsequent patenting is caused solely by capital injection. However, this study provides support for the reasoning that the observable outcome is actually caused by VCs since the reported results of the regression do not estimate a significant effect for the amount VCs invest in start-ups. Furthermore, the findings of this study contribute to the research on the interrelation between VC funding and subsequent patent quality [13]. The regression based on the number of citations of new patent applications reports a positive effect of VC funding on the quality of subsequently filed patent applications.

Second, the regressions show that VC financing substantially influences start-ups' trademarking activities. Already first funding rounds are associated with a significant increase of the number of trademark applications. Extant literature suggests that VCs regard marketing as pivotal for the success of start-ups [60] [61] and that they aim at shifting their focus towards commercialization [11] [19]. The current study adds to this avenue of research by empirically investigating this interrelation through measuring the growth of start-ups' trademark portfolios after VC funding rounds.

Third, this analysis adds to the stream of literature on the varying importance of patents and trademarks as enterprises proceed along the venture cycle [9] [11]. The regressions provide tentative support for a continuous relative growth of start-ups' patent portfolios for first, second and third rounds. This can be interpreted as a continuous relevance of patents during these early stages of the venture cycle. Contrary, an increase in percentage growth for trademark portfolios between first and second rounds is found. Although the originally formulated hypothesis is not completely supported, the findings suggest that VCs promote market orientation as start-ups progress through the venture cycle and hence, the importance of trademarks increases.

Furthermore, this study has various practical implications for both start-ups and VCs. The results of the regressions suggest that VCs promote the patenting of technological knowledge as well as the application of trademarks in order to shift the focus towards commercialization. Entrepreneurs should well be aware of these connections when seeking finance from VCs. Those who do not like their financiers to interfere with their IP strategies may therefore need to consider acquiring capital from other sources. Moreover, entrepreneurs should take into account the varying role of both patents and trademarks along the venture cycle in order to optimally leverage their firms' IP. Whereas patents may be more important at the very early stages of the venture cycle, trademarks gain more and more relevance with the progress of the same. Finally, this paper can help VCs when evaluating start-ups' IP portfolios. Start-ups that already have acquired venture capital might demonstrate broader IP portfolios. This, however, does not necessarily mean a broader technology base and consequently an increased ability to transform knowledge into revenues and profit. Rather, it simply might be that previous VC funding has led to an increased patenting and trademarking activity resulting in larger portfolios. VCs deciding about whether to invest in start-ups that already have acquired venture capital previously need to consider these interrelations. 
Besides various noteworthy contributions to extant literature, this study features a number of limitations. First, the final dataset has been compiled from several sources. Although the manual matching process has been performed with greatest care, the possibility of mismatches cannot be ruled out completely. Especially changes of company names during the time of observation may lead to IP portfolios not being compiled entirely correctly. Another issue related to the underlying dataset is information on the amount of funding allocated by VCs. VentureXpert only contains information about the total amount provided by a VC and no information about how this amount is distributed among rounds. Since funding amounts usually increase with subsequent rounds [46] this may lead to the influence of the capital injection being biased. Second, the number of funding rounds may be only a rough proxy for a start-up's stage within its venture cycle. Future analyses could include other measures such as development of prototypes or generation of first revenues in order to better identify start-ups' development stages and consequently, better quantify the influence of VCs on consecutive patenting and trademarking. Third, this analysis uses a rather generic approach. Future studies could investigate the influence of VCs for different industries. It has been suggested that patenting behavior differs across industries [16] [25] [30]. Consequently, there is reason to assume that the influence of $\mathrm{VC}$ funding on subsequent patenting shows variations as well. Furthermore, it would be interesting to see whether, and if, to what extent the effect of VC funding on IP activity differs among service and manufacturing as wells as between business to customer and customer to customer companies.

\section{JEL Classification}

L26, M31, O34, G24.

\section{References}

[1] Audretsch, D.B., Bönte, W. and Mahagaonkar, P. (2012) Financial Signaling by Innovative Nascent Ventures: The Relevance of Patents and Prototypes. Research Policy, 41, 14071421. https://doi.org/10.1016/j.respol.2012.02.003

[2] Gans, J.S. and Stern, S. (2003) The Product Market and the Market for "Ideas": Commercialization Strategies for Technology Entrepreneurs. Research Policy, 32, 333-350. https://doi.org/10.1016/S0048-7333(02)00103-8

[3] Gruber, M. (2004) Marketing in New Ventures: Theory and Empirical Evidence. Schmalenbach Business Review, 56, 164-199.

[4] Achleitner, A.-K. and Nathusius, E. (2004) Venture Valuation-Bewertung von Wachstumsunternehmen: Klassische und neue Bewertungsverfahren mit Beispielen und Übungsaufgaben. Schäffer-Poeschel, Stuttgart.

[5] Gompers, P.A. and Lerner, J. (2004) The Venture Capital Cycle. 2nd Edition, MIT Press, Cambridge.

[6] Shane, S. and Stuart, T. (2002) Organizational Endowments and the Performance of University Start-Ups. Management Science, 48, 154-170. https://doi.org/10.1287/mnsc.48.1.154.14280

[7] Cao, J.X. and Hsu, P.-H. (2011) The Informational Role of Patents in Venture Capital Financing. Working Paper. http://papers.ssrn.com/sol3/papers.cfm?abstract_id=1678809 
[8] De Clercq, D., Fried, V. H., Lehtonen, O. and Sapienza, H. J. (2006) An Entrepreneur's Guide to the Venture Capital Galaxy. Academy of Management Perspectives, 20, 90-112. https://doi.org/10.5465/AMP.2006.21903483

[9] Mann, R.J. and Sager, T.W. (2007) Patents, Venture Capital, and Software Start-Ups. Research Policy, 36, 193-208. https://doi.org/10.1016/j.respol.2006.10.002

[10] Bertoni, F., Croce, A. and D’Adda, D. (2010) Venture Capital Investments and Patenting Activity of High-Tech Start-Ups: A Micro-Econometric Firm-Level Analysis. Venture Capital, 12, 307-326. https://doi.org/10.1080/13691066.2010.486157

[11] De Vries, G., Pennings, E. and Block, J.H. (2013) Trademark or Patent? The Effects of Market Structure, Customer Type and Venture Capital Financing on Start-Ups' IP Decisions. Working Paper. http://papers.ssrn.com/sol3/papers.cfm?abstract_id=2247281

[12] Hirukawa, M. and Ueda, M. (2011) Venture Capital and Innovation: Which Is First? Pacific Economic Review, 16, 421-465. https://doi.org/10.1111/j.1468-0106.2011.00557.x

[13] Kortum, S. and Lerner, J. (2000) Assessing the Contribution of Venture Capital to Innovation. RAND Journal of Economics, 31, 674-692. https://doi.org/10.2307/2696354

[14] Haeussler, C., Harhoff, D. and Mueller, E. (2009) To Be Financed or Not-The Role of Patents for Venture Capital Financing. Working Paper. http://ftp.zew.de/pub/zew-docs/dp/dp09003.pdf

[15] Cockburn, I.M. and MacGarvie, M.J. (2009) Patents, Thickets and the Financing of EarlyStage Firms: Evidence from the Software Industry. Journal of Economics \& Management Strategy, 18, 729-773. https://doi.org/10.1111/j.1530-9134.2009.00228.x

[16] Graham, S.J., Robert P., Samuelson, P. and Sichelman, T. (2010) High Technology Entrepreneurs and the Patent System: Results of the 2008 Berkeley Patent Survey. Berkeley Technology Law Journal, 24, 1255-1328.

[17] Hayes, D.L. (1999) What the General Intellectual Property Practitioner Should Know about Patenting Business Methods. The Computer Lawyer, 16, 3-18.

[18] Hsu, D.H. and Ziedonis, R.H. (2007) Patents as Quality Signals for Entrepreneurial Ventures. Working Paper. http://proceedings.aom.org/content/2008/1/1.191

[19] Hellmann, T. and Puri, M. (2000) The Interaction between Product Market and Financing Strategy: The Role of Venture Capital. The Review of Financial Studies, 13, 959-984. https://doi.org/10.1093/rfs/13.4.959

[20] Conti, A., Thursby, M. and Rothaermel, F.T. (2011) Show Me the Right Stuff: Signals for High-Tech Startups. NBER Working Paper Series, Working Paper No. 17050.

http://www.nber.org/papers/w17050 https://doi.org/10.3386/w17050

[21] Block, J.H., de Vries., G., Sandner, P.G. and Schumann, J.H. (2012) Trademarks and Venture Capital Funding. Working Paper. http://papers.ssrn.com/sol3/papers.cfm?abstract_id=2064508

[22] Hellmann, T.F. and Puri, M. (2002) Venture Capital and the Professionalization of Start-Up Firms: Empirical Evidence. The Journal of Finance, 57, 169-197. https://doi.org/10.1111/1540-6261.00419

[23] Griliches, Z. (1990) Patent Statistics as Economic Indicators: A Survey. Journal of Economic Literature, 28, 1661-1707. https://doi.org/10.3386/w3301

[24] WIPO (2007) Intellectual Property-Some Basic Definitions. http://www.wipo.int/about-ip/en/

[25] Cohen, W.M., Nelson, R.R. and Walsh, J.P. (2000) Protecting Their Intellectual Assets: Ap- 
propriability Conditions and Why US Manufacturing Firms Patent (or Not). NBER Working Paper Series, Working Paper No. 7552. http://www.nber.org/papers/w7552

https://doi.org/10.3386/w7552

[26] Gans, J.S., Hsu, D.H. and Stern, S. (2002) When Does Start-Up Innovation Spur the Gale of Creative Destruction? RAND Journal of Economics, 33, 571-586.

https://doi.org/10.2307/3087475

[27] Arora, A., Ceccagnoli, M. and Cohen, W.M. (2008) R\&D and the Patent Premium. International Journal of Industrial Organization, 26, 1153-1179. https://doi.org/10.1016/j.ijindorg.2007.11.004

[28] Granstrand, O. (2000) The Economics and Management of Intellectual Property: Towards Intellectual Capitalism. Edward Elgar, Cheltenham.

[29] Long, C. (2002) Patent Signals. The University of Chicago Law Review, 69, 625-679. https://doi.org/10.2307/1600501

[30] Mansfield, E. (1986) Patents and Innovation: An Empirical Analysis. Management Science, 32, 173-181. https://doi.org/10.1287/mnsc.32.2.173

[31] Greenhalgh, C. and Rogers, M. (2006) Intellectual Property Activity by Service Sector and Manufacturing Firms in the UK, 1996-2000. Intellectual Property Research Institute of Australia, Working Paper No. 3/06. http://citeseerx.ist.psu.edu/viewdoc/download?doi=10.1.1.509.2012\&rep=rep1\&type=pdf

[32] Arundel, A. and Kabla, I. (1998) What Percentage of Innovations Are Patented? Empirical Estimates for European Firms. Research Policy, 27, 127-141. https://doi.org/10.1016/S0048-7333(98)00033-X

[33] Helmers, C. and Rogers, M. (2008) Does Patenting Help High-Tech Start-Ups? Working Paper.

http://www.epip.eu/conferences/epip03/papers/Rogers_HelmersRogersEPIPPatents140920 $\underline{08 . p d f}$

[34] Cockburn, I. M. and Wagner, S. (2007) Patents and the Survival of Internet-Related IPOs. NBER Working Paper Series, Working Paper No. 13146.

http://www.nber.org/papers/w13146 https://doi.org/10.3386/w13146

[35] Helmers, C. and Rogers, M. (2010) Innovation and the Survival of New Firms in the UK. Review of Industrial Organization, 36, 227-248. https://doi.org/10.1007/s11151-010-9247-7

[36] Lerner, J. (1994) The Importance of Patent Scope: An Empirical Analysis. RAND Journal of Economics, 25, 319-333. https://doi.org/10.2307/2555833

[37] Cohen, D. (1991) Trademark Strategy Revisited. Journal of Marketing, 55, 46-59. https://doi.org/10.2307/1252147

[38] Mendonça, S., Pereira, T.S. and Godinho, M.M. (2004) Trademarks as an Indicator of Innovation and Industrial Change. Research Policy, 33, 1385-1404. https://doi.org/10.1016/j.respol.2004.09.005

[39] OHIM (2008) What Is a Trade Mark? http://oami.europa.eu/ows/rw/pages/CTM/trademark.en.do

[40] Rujas, J. (1999) Trade Marks: Complementary to Patents. World Patent Information, 21, 35-39. https://doi.org/10.1016/S0172-2190(99)00023-X

[41] Economides, N.S. (1988) The Economics of Trademarks. Trademark Reporter, 78, 523-539.

[42] Landes, W.M. and Posner, R.A. (1987) Trademark Law: An Economic Perspective. Journal of Law and Economics, 30, 265-309. https://doi.org/10.1086/467138 
[43] Hall, B.H., Helmers, C., Rogers, M. and Sena, V. (2012) The Choice between Formal and Informal Intellectual Property: A Literature Review. NBER Working Paper Series, Working Paper No. 17983. http://www.nber.org/papers/w17983 https://doi.org/10.3386/w17983

[44] Flikkema, M.J., De Man, A.-P. and Wolters, M. (2010) New Trademark Registration as an Indicator of Innovation: Results of an Explorative Study of Benelux Trademark Data. Working Paper.

http://www.academia.edu/29494866/New_trademark_registration_as_an_indicator_of_inn ovation_results_of_an_explorative_study_of_Benelux_trademark_data

[45] Jensen, P.H., Webster, E. and Buddelmeyer, H. (2008) Innovation, Technological Conditions and New Firm Survival. The Economic Record, 84, 434-448. https://doi.org/10.1111/j.1475-4932.2008.00509.x

[46] Sahlman, W.A. (1990) The Structure and Governance of Venture-Capital Organizations. Journal of Financial Economics, 27, 473-521. https://doi.org/10.1016/0304-405X(90)90065-8

[47] Gompers, P.A. (1995) Optimal Investment, Monitoring, and the Staging of Venture Capital. The Journal of Finance, 50, 1461-1489. https://doi.org/10.1111/j.1540-6261.1995.tb05185.x

[48] Fitza, M., Matusik, S.F. and Mosakowski, E. (2009) Do VCs Matter? The Importance of Owners on Performance Variance in Start-Up Firms. Strategic Management Journal, 30, 387-404. https://doi.org/10.1002/smj.748

[49] Hsu, D.H. (2004) What Do Entrepreneurs Pay for Venture Capital Affiliation? The Journal of Finance, 59, 1805-1844. https://doi.org/10.1111/j.1540-6261.2004.00680.x

[50] Hsu, D.H. (2006) Venture Capitalists and Cooperative Start-Up Commercialization Strategy. Management Science, 52, 204-219. https://doi.org/10.1287/mnsc.1050.0480

[51] Ivanov, V.I. and Xie, F. (2010) Do Corporate Venture Capitalists Add Value to Start-Up Firms? Evidence from IPOs and Acquisitions of VC-Backed Companies. Financial Management, 39, 129-152. https://doi.org/10.1111/j.1755-053x.2009.01068.x

[52] Caselli, S., Gatti, S. and Perrini, F. (2009) Are Venture Capitalists a Catalyst for Innovation? European Financial Management, 15, 92-111. https://doi.org/10.1111/j.1468-036X.2008.00445.x

[53] Engel, D. (2002) The Impact of Venture Capital on Firm Growth: An Empirical Investigation. Working Paper. http://ideas.repec.org/p/zbw/zewdip/895.html

[54] Conti, A., Thursby, J. and Thursby, M. (2013) Patents as Signals for Startup Financing. NBER Working Paper Series, Working Paper No. 19191. https://doi.org/10.3386/w19191 http://www.nber.org/papers/w19191

[55] Stuart, T., Hoang, H. and Hybels, R.C. (1999) Interorganizational Endorsements and the Performance of Entrepreneurial Ventures. Administrative Science Quarterly, 44, 315-349. https://doi.org/10.2307/2666998

[56] Connelly, B.L., Certo, S.T., Ireland, R.D. and Reutzel, C.R. (2011) Signaling Theory: A Review and Assessment. Journal of Management, 37, 39-67. https://doi.org/10.1177/0149206310388419

[57] Spence, M. (1973) Job Market Signaling. Quarterly Journal of Economics, 87, 355-374. https://doi.org/10.2307/1882010

[58] Lemley, M.A. (2001) Rational Ignorance at the Patent Office. Northwestern University Law Review, 95, 1-34. https://doi.org/10.2139/ssrn.261400

[59] Baum, J.A. and Silverman, B.S. (2004) Picking Winners or Building Them? Alliance, Intellectual, and Human Capital as Selection Criteria in Venture Financing and Performance of 
Biotechnology Startups. Journal of Business Venturing, 19, 411-436.

https://doi.org/10.1016/S0883-9026(03)00038-7

[60] Hisrich, R.D. (1989) Entrepreneurship. McGraw Hill.

[61] Spann, M., Adams, M. and Wortman, M.S. (1988) Entrepreneurship: Definitions, Dimensions and Dilemmas. In: Proceedings of the Third Annual Conference, US Association for Small Business and Entrepreneurship, Kennesaw, GA, 147-153.

[62] Sandner, P.G. and Block, J. (2011) The Market Value of R\&D, Patents, and Trademarks. Research Policy, 40, 969-985. https://doi.org/10.1016/j.respol.2011.04.004

[63] WIPO (2009) Intellectual Property and Small and Medium-Sized Enterprises. http://www.wipo.int/sme/en/

[64] Block, J. and Sandner, P. (2009) What Is the Effect of the Financial Crisis on Venture Capital Financing? Empirical Evidence from US Internet Start-Ups. Venture Capital, 11, 295 309. https://doi.org/10.1080/13691060903184803

[65] Greenhalgh, C., Rogers, M. and Helmers, C. (2007) An Analysis of the Association between the Use of Intellectual Property by UK SMEs and Subsequent Performance. Working Paper. https://www.researchgate.net/publication/228472779_An_analysis_of_the_association_bet ween_the_use_of_intellectual_property_by_UK_SMEs_and_subsequent_performance

[66] Austin, D.H. (1993) An Event-Study Approach to Measuring Innovative Output: The Case of Biotechnology. American Economic Review, 83, 253-258.

[67] Wooldridge, J. (2011) Introductory Econometrics. South-Western, Mason.

\section{Submit or recommend next manuscript to SCIRP and we will provide best service for you:}

Accepting pre-submission inquiries through Email, Facebook, LinkedIn, Twitter, etc.

A wide selection of journals (inclusive of 9 subjects, more than 200 journals)

Providing 24-hour high-quality service

User-friendly online submission system

Fair and swift peer-review system

Efficient typesetting and proofreading procedure

Display of the result of downloads and visits, as well as the number of cited articles

Maximum dissemination of your research work

Submit your manuscript at: http://papersubmission.scirp.org/

Or contact ajibm@scirp.org 